\title{
Synthesis and antimicrobial activity of Ibuprofen derivatives
}

\author{
Ibtihal Q. Abdulla
}

Department of Chemistry, College of Science, University of Tikrit, Salaheddin, Iraq; ibtihal.qahtan@yahoo.com

Received 11 July 2013; revised 11 August 2013; accepted 19 August 2013

Copyright (C) 2014 Ibtihal Q. Abdulla. This is an open access article distributed under the Creative Commons Attribution License, which permits unrestricted use, distribution, and reproduction in any medium, provided the original work is properly cited. In accordance of the Creative Commons Attribution License all Copyrights (c) 2014 are reserved for SCIRP and the owner of the intellectual property Ibtihal Q. Abdulla. All Copyright (C) 2014 are guarded by law and by SCIRP as a guardian.

\section{ABSTRACT}

In order to reduce the ulcerogenic effect of ibuprofen, its carboxylic group has been converted into 5-membered and 6-membered heterocyclic rings. Various 1,3,4-thiadaizo (y), imidazo [2,1-b] $[1,3,4]$ thiadiazoles (1a-d), 1,3-oxazin-2-yl (2), quinazolin-2-yl (3, 4 and 5), hydrazine, pyrazole (6), pyrazone $(7,8)$ and oxadiazole $(9,12)$. Derivatives of ibuprofen were prepared by cyclization under various reaction conditions in a very good yield. The microbial inhibitory effect of the new agents has been assessed in vitro against Gram-positive and Gram-negative bacteria activity. Compounds $(4,5$, and 8$)$ showed the highest antibacterial activities compared to other compounds and standard drugs. However, compound (1b) showed the lowest antibacterial activity compared to other compounds. All compounds have been characterized by IR, ${ }^{1} \mathrm{H}$ NMR and C.H.N analysis.

\section{KEYWORDS}

\section{Ibuprofen; Biological Active Compounds}

\section{INTRODUCTION}

Ibuprofen is (2RS)-1[4-(2-methylpropyl) phenyl] propionic acid [1]. Ibuprofen was the first member of propionic acid derivatives to be introduced in 1969 as a better alternative to aspirin. Gastric discomfort, nausea and vomiting are still the most common side effects though less than aspirin or indomethacin [2,3].

Ibuprofen is effective in reducing high body temperature, and an anti-inflammatory which inhibits normal platelet function. Ibuprofen is reported to be better for joint and muscle pain than other pain killer and has been used by people for arthritis for years. However, it can cause gastrointestinal upset and bleeding [4].

Ibuprofen is usually given as the free acid, also various salts, esters, and other complexes are also used. These include lysing and sodium salts, guaiacol and pyridoxine esters, iso-butanol ammonium and meglumine derivatives [5-7].

In order to reduce the ulcerogenic effect of ibuprofen, its carboxylic group has been converted into 5-membred heterocyclic rings. The cyclized derivatives were screened for their anti-inflammatory activity by the carrageenan induced rat paw edema method and showed $50 \%$ to $86 \%$ inhibition, whereas the started drug ibuprofen showed $92 \%$ inhibition at the same oral dose [8]. A recent literature survey revealed that different heterocyclic moieties have been widely used by the medicinal chemist in the past to explore its biological activities [9,10].

In the present study, we have aimed to achieve a better antimycobacterial profile at lower concentrations, by preparing ibuprofen derivatives. This report deals with the synthesis of ibuprofen derivatives and antimicrobial and antimycobacterial activities.

\section{EXPERIMENTAL WORK}

\subsection{Instrumentation}

Unless otherwise noted, materials were obtained from commercial suppliers and used without further purification, melting points were recorded on electrothermal melting point apparatus. Thin layer chromatography (TLC) controls were carried out on precoated silica gel plates (F254 Merck). The IR spectra were recorded on Shimadzu 8400 FT-IR infrared spectrophotometer using $\mathrm{KBr}$ pellets. ${ }^{1} \mathrm{H}$ NMR spectra were recorded on ${ }^{1} \mathrm{H}$ NMR Bruken utra shield $300 \mathrm{MHz}$. Elemental analysis were carried out using Euro vector EA 3000 A Haly. 


\subsection{Synthesis of 2-Amino-5-(2- (4-Isobutylphenyl) Ethyl-1. 3. 4-Thiadiazole (y)}

Compound (y) was obtained according to the procedure described by Al-Omar et al. [11] and Mazzone et al. [12] with a modification. A mixture of equimolar quantities of ibuprofen $(0.1 \mathrm{~mol})$, thiosemicarbazide $(0.1 \mathrm{~mol})$, and phosphorus oxychloride $(30 \mathrm{ml}$ ) was refluxed gently for half an hour, after cooling water was added $(90 \mathrm{ml})$ and the mixture was reflexed for $4 \mathrm{~h}$ and filtered, the precipitate was filtered and recrystallized from ethanol.

Yield: $80 \%$, M.p. $205^{\circ} \mathrm{C}-208^{\circ} \mathrm{C}$, IR $\left(\mathrm{KBr}, \mathrm{cm}^{-1}\right)$ : 3593 , 3120, 1630. ${ }^{1} \mathrm{H}$ NMR $(\delta$, ppm, DMSO-d6): 0.89 (d, $6 \mathrm{H}$, $\left.\left(\mathrm{CH}_{3}\right)_{2}\right), 1.61\left(\mathrm{~d}, 3 \mathrm{H}, \mathrm{CH}_{3} \mathrm{CH}\right), 1.76-1.84(\mathrm{~m}, 1 \mathrm{H}$, $\mathrm{CHCH}_{3}$ ), 2.55 (d, $2 \mathrm{H}, \mathrm{CH}_{2} \mathrm{Ar}$ ), 3.56 (q, 1H, $\left.\mathrm{CH}_{3} \mathrm{CH}\right), 7$ 10 (m, 4H, ArH), 8.85 (s, 2H, $\mathrm{NH}_{2}$ ).

\subsection{Synthesis 2-(4-Isobutylphenyl) Ethyl-6-(4-Substitutaryl) Imidazo [2,1-b] $[1,3,4]$ Thiadiazoles (1a-d) [13]}

Compound (y) (0.01 mol) and an appropriate $\alpha$-bromoketones $(0.01 \mathrm{~mol})$ was reflexed in dry ethanol (300 $\mathrm{ml}$ ) for $10 \mathrm{~h}$, excess of solvent was removed under reduced pressure the solid hydrobromide salts suspended in water, and neutralized by aqueous sodium carbonate solution to get free base, it was filtered, washed with water, dried and recrystallized from suitable solvent. 2-(4-Isobutylphenyl) ethyl-6-phenylimidazo [2,1-b] [1,3,4] thiadiazoles (1a) yield: $70 \%$, M.p. $215^{\circ} \mathrm{C}-217^{\circ} \mathrm{C}$, IR $(\mathrm{KBr}$, $\left.\mathrm{cm}^{-1}\right)$ : 3095, 3033, 2943, 1576, 1490, 1339,1130, 843. ${ }^{1} \mathrm{HNMR}\left(\delta\right.$, ppm, DMSO-d6): 0.88 (d, $\left.6 \mathrm{H},\left(\mathrm{CH}_{3}\right) 2\right), 1.61$ (d, $3 \mathrm{H}, \mathrm{CH}_{3} \mathrm{CH}$ ), 1.95 - 2.08 (m, $1 \mathrm{H}, \mathrm{CHCH}_{3}$ ), 2.59 (d, $2 \mathrm{H}, \mathrm{CH}_{2} \mathrm{Ar}$ ), 3.56 (q, $\left.1 \mathrm{H}, \mathrm{CH}_{3} \mathrm{CH}\right), 7.28-7.40(\mathrm{~m}, 9 \mathrm{H}$, $\mathrm{ArH}), 8.75$ (s, $1 \mathrm{H}, \mathrm{H}-5$ imidazole).

2-(4-Isobutylphenyl)ethyl-6-(4-methylphenyl)imidazo [2,1-b] [1,3,4] thiadiazoles (1b) yield: $73 \%$, M.p. $196^{\circ} \mathrm{C}$ $198^{\circ} \mathrm{C}$, IR $\left(\mathrm{KBr}, \mathrm{cm}^{-1}\right)$ : 3085, 3043, 2973, 1596, 1481, 1343,1150, 843. ${ }^{1} \mathrm{HNMR}$ (400 MHz, $\delta$, ppm, DMSO-d6): 0.83 (d, 6H, $\left.\left(\mathrm{CH}_{3}\right) 2\right), 1.46$ (d, 3H, $\left.\mathrm{CH}_{3} \mathrm{CH}\right), 1.12$ - 1.51 $\left(\mathrm{m}, 1 \mathrm{H}, \mathrm{CHCH}_{2}\right), 2.49\left(\mathrm{~d}, 2 \mathrm{H}, \mathrm{CH}_{2} \mathrm{Ar}\right), 3.52(\mathrm{q}, 1 \mathrm{H}$, $\mathrm{CH}_{3} \mathrm{CH}$ ), 7.08 - 7.18 (m, 4H, $\left.\mathrm{ArH}\right), 8.15$ (d, 2H, Ar), 8.30 (d,2H, Ar), 8.74 (s, 1H, H-5 imidazole).

2-(4-Isobutylphenyl) ethyl-6-(4-methoxyphenyl) imidazo [2,1-b] [1,3,4] thiadiazoles (1c) yield: 70\%, M.p. $216^{\circ} \mathrm{C}-218^{\circ} \mathrm{C}$, IR $\left(\mathrm{KBr}, \mathrm{cm}^{-1}\right): 3085,3043,2973,1596$, 1481, 1343,1150, 843. ${ }^{1} \mathrm{HNMR}(400 \mathrm{MHz}, \delta, \mathrm{ppm}$, DMSO-d6): 0.88 (d, 6H, $\left.\left(\mathrm{CH}_{3}\right) 2\right), 1.29$ (d, 3H, $\left.\mathrm{CH}_{3} \mathrm{CH}\right)$, 2.36 - 2.39 (m, $\left.1 \mathrm{H}, \mathrm{CHCH}_{3}\right), 2.43$ (d, $\left.2 \mathrm{H}, \mathrm{CH}_{2} \mathrm{Ar}\right), 3.76$ (q, $\left.1 \mathrm{H}, \mathrm{CH}_{3} \mathrm{CH}\right), 7.11-7.26$ (m, 4H, ArH), 7.40 (m, 5H, ArH), 8.75 (s, 1H, H-5 imidazole).

2-(4-Isobutylphenyl) ethyl-6-(4-nitrophenyl) imidazo [2,1-b] [1,3,4] thiadiazoles (1d) yield: $70 \%$, M.p. $205^{\circ} \mathrm{C}$ $210^{\circ} \mathrm{C}$, IR $\left(\mathrm{KBr}, \mathrm{cm}^{-1}\right)$ : 3060, 3021, 2959, 1587, 1494,
1346,1128. ${ }^{1} \mathrm{HNMR}(400 \mathrm{MHz}, \delta$, ppm, DMSO-d6): 0.86 (d, 6H, $\left.\left(\mathrm{CH}_{3}\right) 2\right), 1.80$ (d, 3H, $\left.\mathrm{CH}_{3} \mathrm{CH}\right), 1.95-2.08$ (m, $\left.1 \mathrm{H}, \mathrm{CHCH}_{3}\right), 2.47\left(\mathrm{~d}, 2 \mathrm{H}, \mathrm{CH}_{2} \mathrm{Ar}\right), 3.76\left(\mathrm{q}, 1 \mathrm{H}, \mathrm{CH}_{3} \mathrm{CH}\right)$, 7.16 - 7.37 (m, 4H, ArH), 7.14 - 7.31 (m, 4H, ArH), 8.40 (d, 2H, ArH), 8.16 (d, 2H, ArH), 8.85 (s, 1H, H-5 imidazole)

\subsection{Synthesis 1-(4-Oxo-4H-Benzo [d] [1,3] Oxazin-2-yl) Ibuprofen (2)}

A solution of acid chloride ( $5 \mathrm{mmol}$ ) in dry pyridine $(30 \mathrm{ml})$, was reflexed for $3 \mathrm{~h}$ the reaction mixture was cooled and poured into cold diluted $\mathrm{HCl}$, the solid that separated filtered off and recrystallized from benzene to give (2), yield: $77 \%$, M.p. $202^{\circ} \mathrm{C}-204^{\circ} \mathrm{C}$, IR $\left(\mathrm{KBr}, \mathrm{cm}^{-1}\right)$ : $3044,2920,2850,1745,1600 .{ }^{1} \mathrm{H}$ NMR $(\delta, \mathrm{ppm}$, DMSO-d6): 0.89 (d, 6H, $\left(\mathrm{CH}_{3}\right) 2$ ), 1.31 (d, $3 \mathrm{H}, \mathrm{CH}_{3} \mathrm{CH}$ ), 1.76 - 1.82 (m, 1H, $\mathrm{CHCH}_{3}$ ), 2.43 (d, $2 \mathrm{H}, \mathrm{CH}_{2} \mathrm{Ar}$ ), 3.71 (q, $\left.1 \mathrm{H}, \mathrm{CH}_{3} \mathrm{CH}\right), 7.15-7.66(\mathrm{~m}, 4 \mathrm{H}, \mathrm{ArH})$ for ibuprofen, 7.0 - $7.3(\mathrm{~m}, 4 \mathrm{H}, \mathrm{ArH})$ for anthranilic acid.

\subsection{Synthesis 1-(4-Oxo-4H-Benzo [d] [1,3] Oxazin-2-yl) lbuprofen (2)}

A solution of acid chloride (5 mmol) in dry pyridine $(30 \mathrm{ml})$, was reflexed for $3 \mathrm{~h}$ the reaction mixture was cooled and poured into diluted $\mathrm{HCl}$, the solid that separated filtered off and recrystallized from benzene to give (2), yield: 77\%, M.p.202-204C, IR $\left(\mathrm{KBr}, \mathrm{cm}^{1}\right)$ : $3044,2920,2850,1745,1600 .{ }^{1} \mathrm{H}$ NMR $(\delta, \mathrm{ppm}$, DMSO-d6): 0.89 (d, 6H, (CH3) $)$ ), 1.31 (d, 3H, $\mathrm{CH}_{3} \mathrm{CH}$ ), 1.76 - $1.82\left(\mathrm{~m}, 1 \mathrm{H}, \mathrm{CHCH}_{3}\right), 2.43$ (d, $\left.2 \mathrm{H}, \mathrm{CH}_{2} \mathrm{Ar}\right), 3.71$ (q, $\left.1 \mathrm{H}, \mathrm{CH}_{3} \mathrm{CH}\right), 7.15-7.66(\mathrm{~m}, 4 \mathrm{H}, \mathrm{ArH})$, for ibuprofen, 7.0-7.3 (m, 4H, ArH) for anthranilic acid.

\subsubsection{Synthesis of 1-(3-Oxo-3, 4-Dihydroquinazolin-2-yl) Ibuprofen (3)}

A mixture of (3) (6 mmol) and ammonium acetate (6 $\mathrm{mmol}$ ) was fused in an oil bath for $2 \mathrm{~h}$, then poured into water, the separation solid after concentration and cooling was filtered off and recrystallized from ethanol to give (4), yield $66 \%$, M.p. $217^{\circ} \mathrm{C}-219^{\circ} \mathrm{C}$, IR $\left(\mathrm{KBr}, \mathrm{cm}^{-1}\right)$ : 3325, 2910, 2850, 1589, 1349.

\subsubsection{Synthesis of 1-(3-Thioxo-3, 4-Dihydroquinazolin-2-yl) Ibuprofen (4)}

A mixture of (4) (5 mmol) and phosphorus pentasulfide (5 mmol) in dry xylene $(50 \mathrm{ml})$ was heated under reflux for $1 \mathrm{~h}$, then concentration the solution, the product was obtained by filtration and recrystallized from xylene to give (5), yield $68 \%$, M.p. $222^{\circ} \mathrm{C}-224^{\circ} \mathrm{C}$, IR (KBr, $\left.\mathrm{cm}^{-1}\right)$ : 3260, 2920, 2850, 1587, 1325. ${ }^{1} \mathrm{HNMR}(\delta$, ppm, DMSO-d6): 0.89 (d, 6H, $\left.\left(\mathrm{CH}_{3}\right) 2\right), 1.48$ (d, 3H, $\left.\mathrm{CH}_{3} \mathrm{CH}\right)$, 1.12 - $1.51\left(\mathrm{~m}, 1 \mathrm{H}, \mathrm{CHCH}_{3}\right), 2.55$ (d, $\left.2 \mathrm{H}, \mathrm{CH}_{2} \mathrm{Ar}\right), 3.56$ (q, $1 \mathrm{H}, \mathrm{CH}_{3} \mathrm{CH}$ ), 7.10 - 7.18 (m, 4H, ArH), 6.5 - 7.2 (m, 4H, ArH), 9.1 (s, 1H, NH, exchangeable). 


\subsubsection{Synthesis of 1-[4-(5-Amino $[1,3,4]$ Thiadiazol-2-yl) Quinazolin-2-yl] Ibuprofen (5)}

A mixture of (5) (5 mmol) and thiosemicarbazide (5 $\mathrm{mmol}$ ) and phosphorus oxychloride (5 mmol) was warmed at $60^{\circ} \mathrm{C}$ for $1 \mathrm{~h}$ and the temperature was raised to $90^{\circ} \mathrm{C}$ for additional $2 \mathrm{~h}$, the contents were poured onto crashed ice, cooled to $10^{\circ} \mathrm{C}, \mathrm{pH}$ adjusted to $8-10 \mathrm{M} \mathrm{NaOH}$ and the resulting solid was crystallized from DMF to give (6), yield $63 \%$, M.p. $231^{\circ} \mathrm{C}-233^{\circ} \mathrm{C}$, IR $\left(\mathrm{KBr}, \mathrm{cm}^{-1}\right)$ : 3200 , 1620, 1210, 1075, 980. ${ }^{1} \mathrm{H}$ NMR ( $\delta$, ppm, DMSO-d6): 0.98 (d, 6H, $\left.\left(\mathrm{CH}_{3}\right) 2\right), 1.53$ (d, 3H, $\left.\mathrm{CH}_{3} \mathrm{CH}\right), 1.74-1.78$ (m, $1 \mathrm{H}, \mathrm{CHCH}_{2}$ ), 2.39 (d, 2H, $\left.\mathrm{CH}_{2} \mathrm{Ar}\right), 3.56(\mathrm{q}, 1 \mathrm{H}$, $\left.\mathrm{CH}_{3} \mathrm{CH}\right), 7.16$ - 7.37 (m, 4H, ArH), 6.2 - $7.2(\mathrm{~m}, 4 \mathrm{H}$, $\mathrm{ArH}), 8.81\left(\mathrm{~s}, 1 \mathrm{H}, \mathrm{NH}_{2}\right)$.

\subsection{Synthesis of Ibuprofen Hydrazide $(z)^{14}$}

A mixture of ibuprofen $(0.03 \mathrm{~mol})$ and phosphorus pentachloride $(0.07 \mathrm{~mol})$ in a hydrous carbon tetrachloride $(20 \mathrm{ml})$ were refluxed for $2 \mathrm{~h}$ at $100^{\circ} \mathrm{C}$, the solvent was distilled off for further reaction without any purification. To the ibupronoyl chloride $(0.03 \mathrm{~mol})$ was added hydrazine hydrate $(0.1 \mathrm{~mol})$ dropwise below $5^{\circ} \mathrm{C}$ and the resultant mixture was stirred for $5 \mathrm{~h}$ at room temperature. A solid that separated out was washed with aqueous $\mathrm{NaHCO}_{3}(10 \%)$ and dried in vaccuoum, it was recrystallized from methanol to obtain pure crystalline solid $\mathrm{z}$, yield: $76 \%$, M.p. $188^{\circ} \mathrm{C}-200^{\circ} \mathrm{C}$, IR $\left(\mathrm{KBr}, \mathrm{cm}^{-1}\right)$ : 3335 $\left(\mathrm{NH}, \mathrm{NH}_{2}\right), 1345(\mathrm{CN}), 1628(\mathrm{C}=\mathrm{N}), 1680(\mathrm{C}=\mathrm{O})$.

\subsection{Synthesis of Compounds $(6-8,9)[15]$}

To a solution of (z) $(0.001 \mathrm{~mol})$ in ethanol $(10 \mathrm{ml})$ appropriate diketone (ethylacetoacetate, acetylacetone, ethylcyanoacetate) (0.002 mol) was added and the reaction mixture was reflexed on a water bath for $12 \mathrm{~h}$ in presence of catalytic amount of glacial acetate acid (2 - 3 drops), the reaction contents were cooled to room temperature and the obtained product $(7,8,9)$ was filtered, dried and purified by recrystallization from ethanol.

\subsubsection{Synthesis of 5-[2-(4-Isobutylphenyl) Etha- none]-3, 5-Dimethyl-1H-Pyrazol (6)}

Yield 71\%, M.p. $265^{\circ} \mathrm{C}-266^{\circ} \mathrm{C}$, IR $\left(\mathrm{KBr}, \mathrm{cm}^{-1}\right): 1683$ $(\mathrm{C}=\mathrm{O}), 1622(\mathrm{C}=\mathrm{N}), 1350(\mathrm{C}-\mathrm{N}) .{ }^{1} \mathrm{HNMR}(\delta, \mathrm{ppm}$, DMSO-d6): 0.87 (d, 6H, $\left.\left(\mathrm{CH}_{3}\right) 2\right), 1.29$ (d, 3H, $\mathrm{CH}_{3} \mathrm{CH}$ ), 1.76 - 1.85 (m, $1 \mathrm{H}, \mathrm{CHCH}_{3}$ ), 2.42 (d, $2 \mathrm{H}, \mathrm{CH}_{2} \mathrm{Ar}$ ), 3.74 (q, $1 \mathrm{H}, \mathrm{CH}_{3} \mathrm{CH}$ ), 7.15 - 7.66 (m, 4H, ArH), 2.76 (s, 3H, $\mathrm{CH}_{3}$ pyrazole), 5.9 (s, $1 \mathrm{H}, \mathrm{CH}$ pyrazole).

\subsubsection{Synthesis of 5-[2-(4-Isobutylphenyl) Etha- none]-3-Methyl-1H-Pyrazol-5(4H)- One (7) \\ Yield $76 \%$, M.p. $240^{\circ} \mathrm{C}-242^{\circ} \mathrm{C}$, IR $\left(\mathrm{KBr}, \mathrm{cm}^{-1}\right)$ : 1722 ,}

$1718(\mathrm{C}=\mathrm{O}), 1615(\mathrm{C}=\mathrm{N}) .{ }^{1} \mathrm{H}$ NMR $(\delta$, ppm, DMSO-d6): 0.88 (d, 6H, $\left.\left(\mathrm{CH}_{3}\right) 2\right), 1.26$ (d, 3H, $\left.\mathrm{CH}_{3} \mathrm{CH}\right), 1.78-1.85$ $\left(\mathrm{m}, 1 \mathrm{H}, \mathrm{CHCH}_{2}\right), 2.43\left(\mathrm{~d}, 2 \mathrm{H}, \mathrm{CH}_{2} \mathrm{Ar}\right), 3.62(\mathrm{q}, 1 \mathrm{H}$, $\mathrm{CH}_{3} \mathrm{CH}$ ), 7.08 - 7.26 (m, 4H, ArH), 0.9 (s, 3H, CH pyrazole).

\subsubsection{Synthesis of 5-[2-(4-Isobutylphenyl) Etha- none]-3-Amino-1H-Pyrazol-5(4H)- One (8)}

Yield 66\%, M.p. $214^{\circ} \mathrm{C}-216^{\circ} \mathrm{C}$, IR $\left(\mathrm{KBr}, \mathrm{cm}^{-1}\right)$ : 3425 (NH), $1710(\mathrm{C}=\mathrm{O}), 1646(\mathrm{C}=\mathrm{N}), 1330(\mathrm{C}-\mathrm{N}) .{ }^{1} \mathrm{H}$ NMR ( $\delta$, ppm, DMSO-d6): 0.83 (d, 6H, $\left.\left(\mathrm{CH}_{3}\right) 2\right), 1.28$ (d, 3H, $\mathrm{CH}_{3} \mathrm{CH}$ ), $1.78-2.35\left(\mathrm{~m}, 1 \mathrm{H}, \mathrm{CHCH}_{2}\right), 2.99$ (d, $2 \mathrm{H}$, $\mathrm{CH}_{2} \mathrm{Ar}$ ), 3.70 (q, $1 \mathrm{H}, \mathrm{CH}_{3} \mathrm{CH}$ ), $7.10-7.18$ (m, 4H, $\mathrm{ArH}$ ), 2.06 (s, $2 \mathrm{H}, \mathrm{NH}_{2}$ ), 2.4 (s, $2 \mathrm{H}, \mathrm{CH}_{2}$ ).

\subsection{Synthesis of 5-[2-4-Isobutylphenyl) Ethyl]-5- Substituted-1, 3, 4-Oxadiazole (9-12)}

A mixture of $\mathrm{x}(0.001 \mathrm{~mol})$, substituted aromatic acids (0.002 mol) and phosphorus oxichloride $(15 \mathrm{ml})$ was reflexed on oil bath at $100^{\circ} \mathrm{C}-110^{\circ} \mathrm{C}$ for $6 \mathrm{~h}$, the excess of phosphorus oxichloride was distilled off and cooled residue was poured into ice cold. The contents were neutralized with ammonia to offered crude products (15 - 18), which were filtered, dried and purified by recrystallization from 1,4-dioxane.

(9) Yield $76 \%$, M.p. $260^{\circ} \mathrm{C}-262^{\circ} \mathrm{C}$, IR $\left(\mathrm{KBr}, \mathrm{cm}^{-1}\right)$ : 1605, $1551(\mathrm{C}=\mathrm{N})$. 1HNMR $(\delta$, ppm, DMSO-d6): 0.89 (d, 6H, $\left.\left(\mathrm{CH}_{3}\right) 2\right), 1.46$ (d, 3H, $\left.\mathrm{CH}_{3} \mathrm{CH}\right), 2.35-2.38$ (m, $\left.1 \mathrm{H}, \mathrm{CHCH}_{2}\right), 2.59$ (d, $\left.2 \mathrm{H}, \mathrm{CH}_{2} \mathrm{Ar}\right), 3.77\left(\mathrm{q}, 1 \mathrm{H}, \mathrm{CH}_{3}\right.$ $\mathrm{CH}), 7.12$ - 8.82 (m, 9H, ArH).

(10) Yield 56\%, M.p. $263^{\circ} \mathrm{C}-265^{\circ} \mathrm{C}$, IR $\left(\mathrm{KBr}, \mathrm{cm}^{-1}\right)$ : 1635, $1578(\mathrm{C}=\mathrm{N}), 1148(\mathrm{C}-\mathrm{O}-\mathrm{C}) .{ }^{1} \mathrm{HNMR}(\delta, \mathrm{ppm}$, DMSO-d6): 0.86 (d, 6H, $\left.\left(\mathrm{CH}_{3}\right) 2\right), 1.48$ (d, 3H, $\left.\mathrm{CH}_{3} \mathrm{CH}\right)$, 2.31 - 2.36 (m, 1H, $\mathrm{CHCH}_{2}$ ), 2.43 (d, $\left.2 \mathrm{H}, \mathrm{CH} 2 \mathrm{Ar}\right), 3.40$ (q, $\left.1 \mathrm{H}, \mathrm{CH}_{3} \mathrm{CH}\right), 7.11-8.26$ (m, 9H, $\left.\mathrm{ArH}\right), 3.76$ (s, 2H, $\mathrm{CH}_{2}$ ).

(11) Yield 656\%, M.p. $281^{\circ} \mathrm{C}-283^{\circ} \mathrm{C}$, IR $\left(\mathrm{KBr}, \mathrm{cm}^{-1}\right)$ : 1686-1599 (C=N), 1150 (C-O-C), 714 (C-Br). ${ }^{1} \mathrm{H}$ NMR ( $\delta$, ppm, DMSO-d6): 0.91 (d, 6H, $\left.\left(\mathrm{CH}_{3}\right) 2\right), 1.46$ (d, 3H, $\left.\mathrm{CH}_{3} \mathrm{CH}\right), 1.95-2.08\left(\mathrm{~m}, 1 \mathrm{H}, \mathrm{CHCH}_{2}\right), 2.51$ (d, $2 \mathrm{H}, \mathrm{CH}_{2}$ $\mathrm{Ar}), 3.59\left(\mathrm{q}, 1 \mathrm{H}, \mathrm{CH}_{3} \mathrm{CH}\right), 7.16-8.32(\mathrm{~m}, 8 \mathrm{H}, \mathrm{ArH})$.

(12) Yield $63 \%$, M.p. $223^{\circ} \mathrm{C}-225^{\circ} \mathrm{C}$, IR $\left(\mathrm{KBr}, \mathrm{cm}^{-1}\right)$ : 1665-1585 (C=N), 1155 (C-O-C). ${ }^{1} \operatorname{HNMR}(\delta, \mathrm{ppm}$, DMSO-d6): 0.92 (d, 6H, $\left.\left(\mathrm{CH}_{3}\right) 2\right), 0.77$ (d, 3H, $\left.\mathrm{CH}_{3} \mathrm{CH}\right)$, 1.76 - 1.84 (m, $1 \mathrm{H}, \mathrm{CHCH}_{2}$ ), 2.57 (d, $\left.2 \mathrm{H}, \mathrm{CH}_{2} \mathrm{Ar}\right), 3.70$ (q, $\left.1 \mathrm{H}, \mathrm{CH}_{3} \mathrm{CH}\right), 7.44-8.83$ (m, 8H, ArH).

\section{RESULTS AND DISCUSSION}

2-amino-5-(4-i-butylphenyl)ethyl-1,3,4-thiadiazole (y) was obtained by direct cyclization of a ibuprofen and thi- 
osemicarbazide in the presence of phosphorus oxychloride, the latter reflexed with substituted $\alpha$-haloarylketones in dry ethanol yielded the imidazothiadiazole (1a-d) in good yield. It is well established that this reaction proceeds via the intermediate iminothiadiazole [4], which undergoes dehydrocyclization to form the desired fused heterocycle under reflux temperature spontaneously. The electronic and steric factors at 5th position of 2-amino5-substituted-1,3,4-thiadiazole are crucial in determining the course of its reaction with substituted $\alpha$-haloarylketones the strongly electronegative groups impart less nucleophilic character to the nitrogen at 4th position of the 1,3,4-thiadiazole. Various $\alpha$-haloarylketones were prepared by the bromination of corresponding ketones.

The formation (y) by the reaction between ibuprofen and thiosemicarbazide was confirmed by IR spectra, which showed the presence of amino $\left(-\mathrm{NH}_{2}\right)$ band and absence of carbonyl stretching of carboxylic acid.The structure of imidothiazole derivatives (1a-d) were established by the absence of amino $\left(-\mathrm{NH}_{2}\right)$ band in IR spectra and appearance of imidazole proton (H-5) around $\delta 8.6$ in the ${ }^{1} \mathrm{H}$ NMR spectra, the synthetic route of the compounds (y and 1a-d) is outlined in Figure 1.

The required 1-(4-oxo-4H-benzo[d] [1,3] oxazin-2-yl) ibuprofen (2) was synthesized by reflexing chloroibuprofen (x) with anthranilic acid in boiling pyridine. The reactivity of nitrogen nucleophiles was investigated aiming for synthesis of novel heterocyclic synthesis of interest application. Thus, the reaction of (z) with ammonium acetate afforded quinazolinone derivatives (3), the interaction of 3 with $\mathrm{P}_{2} \mathrm{~S}_{5}$ in dry xylene afforded quinazolin-3H-4-thione derivative (4). In the present investigation, the consideration of 4 with thiosemicarbazide using phosphorus oxychloride [14] gave (5) (Figure 2). For the synthesis of the compounds (6 - 12), the sequence of reactions shown in Figure 3. The reaction of ibuprofen hydrazide (z) with appropriate diketone in ethanol in the presence of glacial acetic acid. The structures of compounds (6 - 8) were established by means of IR, ${ }^{1} \mathrm{H}$ NMR and elemental analysis. The C.H.N. analysis data for som of the syanthesized compounds is given in Table 1 . The infrared spectra display a $\mathrm{C}=\mathrm{O}$ stretching on at (1700 $\left.1775 \mathrm{~cm}^{-1}\right)$ and the presence of bands at (1551 - 1686 $\mathrm{cm}^{-1}$ ) for $\mathrm{C}=\mathrm{N}$ and disappearance of $\left(\mathrm{NH}_{2}\right)$ bands, furthermore, the $1 \mathrm{H}$ NMR spectra showed disappeared $\mathrm{NH}_{2}$ and the presence of singlet at $\delta 2.2 \mathrm{ppm}$ for $\mathrm{CH}_{2}$ (pyrazole) ring. The oxadiazole derivatives (9 ) were proofed by IR which showed absorption peak at $\left(1560 \mathrm{~cm}^{-1}\right)$ due to $\mathrm{C}=\mathrm{N}$ Stretch vibration, is structure was further supported by its ${ }^{1} \mathrm{H}$ NMR spectra, which showed the $\mathrm{NH}_{2}$ disappeared and multiplet was obtained in the aromatic region at $\delta$ ppm for sub. ArH protons. The synthesized compounds (6 - 12) were recorded in Figure 3.

\section{Biological Activity}

Since the prepared ibuprofen derivatives in this work were built from two biologically active components (5 and 6-membered heterocyclic rings) they were expected to possess biological activity, thus studies on the antibacterial activity of synthesized ibuprofen derivatives have been carried out against two pathogenic organisms including Staphylococcus aureous (Gram positive) and Escherichia coli (Gram negative) using cup-plate method. The results of the antibacterial studies are shown in Table 2. It was noticeable that the nature of substituted on heterocyclic molecules affected their biological activities against the studied bacteria 15. Thus, among the tested compounds $(1 \mathrm{~d}, 11,12)$ which were substituted with $(\mathrm{Cl}$ or $\mathrm{NO}_{2}$ ) groups showed high biological activity against Escherichia coli and slight to moderate activity against Staphylococcus aureous. Compound (1c) which was substituted with $\left(\mathrm{OCH}_{3}\right)$ group showed high biological activity against Staphylococcus aureous while it showed slight activity against the bacteria.

All compounds other showed high activity against Gram positive bacteria and Gram negative bacteria represented by large inhibition zones.

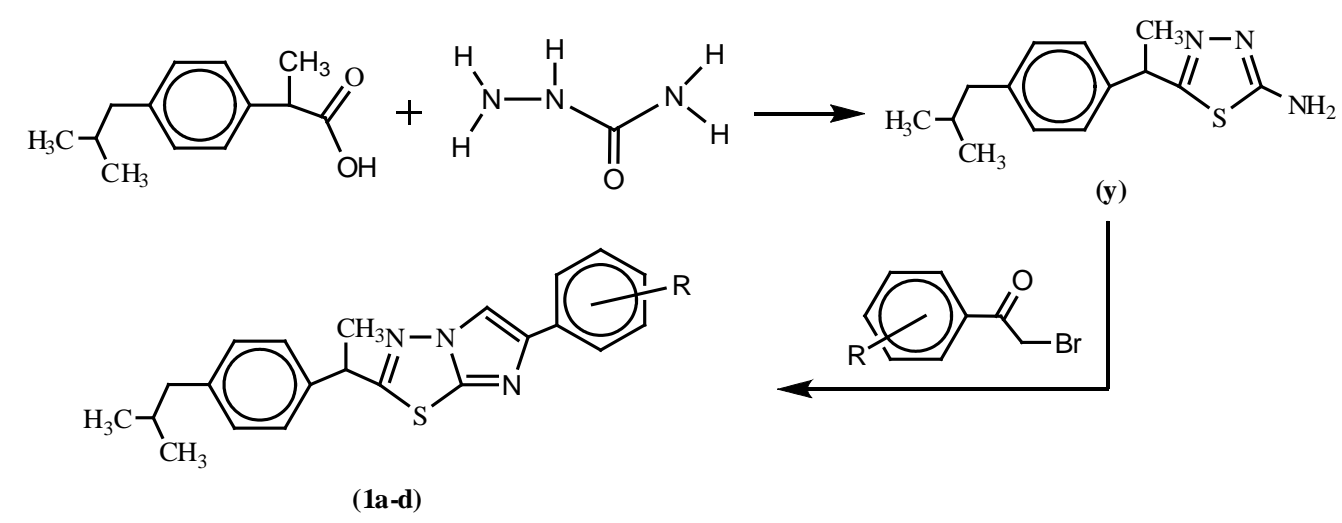

Figure 1. Synthesis compounds (1a-1d). 
<smiles></smiles>

(5)<smiles>CC(C)c1ccc(C(C)c2nc3ccccc3c(=O)[nH]2)cc1</smiles>

(3)<smiles>CC(C)c1ccc(C(C)c2nc3ccccc3c(=O)o2)cc1</smiles>

(2)<smiles></smiles>

(x)

Figure 2. Synthesis compounds (2 - 5).<smiles>CC(C)C(C)c1ccc(C(C)C(C)C(C)C(=O)O)cc1</smiles>

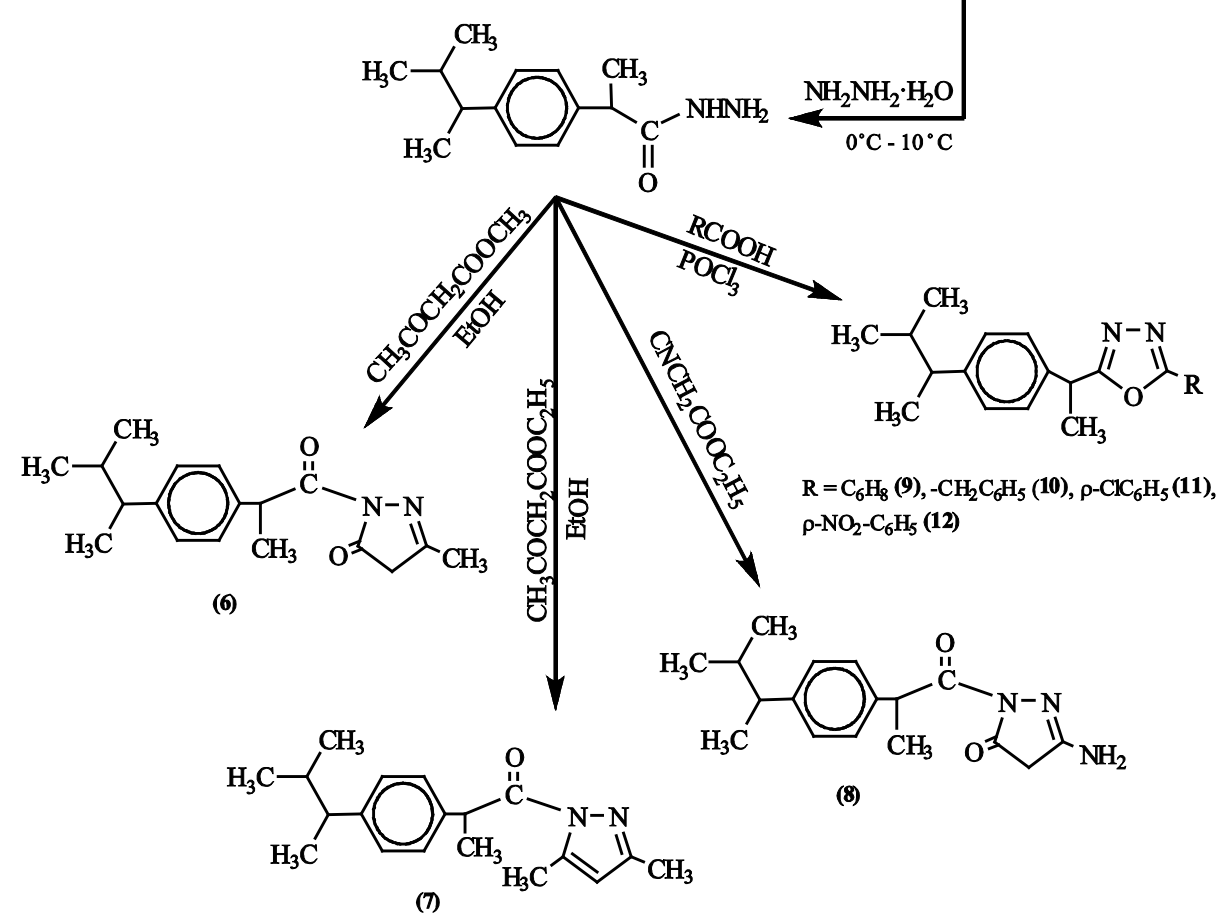

Figure 3. Synthesis compounds (6 - 12). 
Table 1. C.H.N analysis for some of the prepared compounds.

\begin{tabular}{ccccccc}
\hline \multirow{2}{*}{$\begin{array}{c}\text { Compounds } \\
\text { No. }\end{array}$} & \multicolumn{3}{c}{ Calculated } & \multicolumn{3}{c}{ Found } \\
\cline { 2 - 7 } & $\mathrm{C} \mathrm{\%}$ & $\mathrm{H} \%$ & $\mathrm{~N} \%$ & $\mathrm{C} \%$ & $\mathrm{H} \%$ & $\mathrm{~N} \%$ \\
\hline $\mathrm{y}$ & 63.560 & 7.630 & 16.880 & 63.601 & 7.528 & 16.747 \\
$1 \mathrm{a}$ & 85.496 & 5.852 & 10.687 & 85.328 & 5.648 & 10.625 \\
2 & 78.175 & 7.840 & 4.560 & 78.096 & 7.839 & 4.426 \\
4 & 74.534 & 5.832 & 8.695 & 74.436 & 5.823 & 8.657 \\
5 & 69.613 & 6.077 & 15.469 & 69.626 & 6.135 & 15.451 \\
6 & 72.483 & 7.382 & 9.395 & 72.327 & 7.355 & 8.974 \\
8 & 63.878 & 7.984 & 10.969 & 63.903 & 7.792 & 10.958 \\
9 & 78.931 & 7.189 & 9.150 & 78.377 & 7.058 & 9.035 \\
\hline
\end{tabular}

Table 2. Antibacterial activity of compounds (1, 1a-d) and (2 12).

\begin{tabular}{ccc}
\hline \multirow{2}{*}{$\begin{array}{c}\text { Compounds } \\
\text { No. }\end{array}$} & Gram positive bacteria & Gram negative bacteria \\
\cline { 2 - 3 } & Staphylococcus aureous & Escherichia Coli \\
\hline 1 & ++ & ++ \\
$1 \mathrm{a}$ & ++ & +++ \\
$1 \mathrm{~b}$ & + & ++ \\
$1 \mathrm{c}$ & +++ & + \\
$1 \mathrm{~d}$ & + & +++ \\
2 & ++ & ++ \\
3 & ++ & ++ \\
4 & +++ & +++ \\
5 & +++ & +++ \\
6 & ++ & ++ \\
7 & ++ & ++ \\
8 & ++ & +++ \\
9 & ++ & ++ \\
10 & ++ & ++ \\
11 & + & +++ \\
12 & + & +++ \\
\hline
\end{tabular}

\section{CONCLUSION}

The present work reports a new investigation of heterocyclic systems (oxadiazole, oxaziole, thiadiazol, quinazole, pyrazole) derived from Iubprofen. And the systems were prepared with the objective of developing better antibacterial molecules. Among these, compounds (4, 5, and 8) showed maximum activity compared to other compounds. The other prepared compounds also showed maximum activity compared to standard drugs.

\section{REFERENCES}

[1] Bradbury, F. (2004) How important is the role of the physician in the correct use of a drug? An observational cohort study in general practice. International Journal of
Clinical Practice, 144, 27-32.

[2] Tripathi, K.D. (2003) Non-steroidal anti-inflammatory drugs and anti-pyretic analgesics. Essentials of medical pharmacology. 5th Edition, Jaypee Brothers, New Delhi.

[3] Bushra, R. and Aslam, N. (2010) An overview of clinical pharmacology of Ibuprofen. Oman Medical Journal, 25, 155-1661.

[4] Riley, T.R. and Smith, J.P. (1998) Ibuprofen-induced hepatotoxicity in patients with chronic hepatitis C: A case series. American Journal of Gastroenterology, 93, 15631565.

[5] Potthast, H., Dressman, J.P., Junginger, H.E., Midha, K.K., Oeser, H., Shah, V.P., Vogelpoel, H. and Barends, D.M. (2005) Biowaiver Monographs for Immediate Release Solid Oral Dosage Forms: Ibuprofen. Journal of Pharmaceutical Science, 94, 10.

[6] Warner, T.D., Giuliano, F., Vaynovie, I., Bukasa, A., Mitche J.A. and Vave, J.R. (1999) Non-steroid drug selectivities for cyclo-oxygenase-1 rather than cyclo-oxygenase-2 are associated with human gastro intestinal toxicity a full in vitro analysis. Proceedings of National Academy Science of USA, 96, 7563-7568.

[7] Tan, S.C., Patel, B.K., Jackson, S.H., Swift, C.G. and Hutt, J.A. (2002) Stereoselectivity of ibuprofen metabolism and pharmacokinetics following the administration of the racemate to healthy volunteers. Xenobiotica, 32, 683-697.

[8] Mahammad, A. and Shikar K. (2007) Synthesis and evaluation of anti-inflammatory, analgesic, ulcerogenic and lipid peroxidation properties of ibuprofen derivatives. Acta Pharmacy, 57, 31-45.

[9] Demirbas, A., Sahin, D., Demirbas, N. and Karaoglu, S.A. (2009) Synthesis of some new 1,3,4-thiadiazol-2-ylmethyl-1,2,4-triazole derivatives and investigation of their antimicrobial activities. European Journal of Medical Chemistry, 44, 2896-2903.

[10] Radi, M., Crespan, E., Botta, G., Falchi, F., Maga, G., Manetti, F., Corradi, V., Mancini, M., Santucci, M.A., Schenone, S. and Bott, M. (2008) Discovery and SAR of 1,3,4-thiadiazole derivatives as potent Abl tyrosine kinase inhibitors and cytodifferentiating agents. Bioorganic \& Medicinal Chemistry Letters, 18, 1207-1211.

[11] Al-Omar, M., Al-Deeb, O.A., Al-Khamees, H.A. and ElEmam, A.A. (2004) 1,3,4-Thiadizoles. Regioselective ODemethylation on Dehydrative Cyclization of 1-(3,4,5Trimethoxybenzoyl)-4-Substituted Thiosemicarbazides with Sulphuric Acid. Phosphorus Sulfur and Silicon, 179, 2509-2517.

[12] Gadad, A.K., Mahajanshetti, C.S., Nimbalkar, S. and Raichurkar, A. (2000) Synthesis and antibacterial activity of some 5-guanylhydrazone/thiocyanato-6-arylimidazo [2,1b]-1,3,4-thiadiazole-2-sulfonamide derivatives. European Journal of Medical Chemistry, 35, 853-857.

[13] Juddhawala, K.V., Parekh, M.N. and Rawal, B.M. (2011) Synthesis and antibacterial activities of N-chloro aryl acetamide substituted thaizole and 2, 4-thazolidinedione derivatives. A Chive of Applied Science Research, 3, 540548.

[14] Loana, V., Maria, R. and Oana, D. (2013) New deriva- 
tives of aryl-propionic acid. Syanthesis and biologlcal evaluation. Revista Medico-Chirurgicala a Societatii de Medici si Naturalisti din Iasi’s, 2, 532-537.

[15] Mohamed, S.K., Albayati, M., Omara, W.A.M., Abdelhamid, A.A., Potgeiter, H., Hameed, A.S. and Al-Janabi,
K.M. (2012) Functionalization of ibuprofen core structure compound: Part 1 Synthesis of potential chemotherapeutic agents incorporated ibuprofen sub-structure and their in vitro antimicrobial study. Journal of Chemical and Pharmaceutical Research, 4, 3505-3517. 